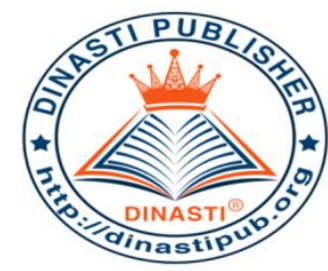

\title{
EMPLOYEE ENGAGEMENT AS A MEDIATOR INFLUENCES OF WORK STRESS AND CAREER DEVELOPMENT TO TURNOVER INTENTION IN EMPLOYEE OFFICE OF PT PKSS CENTRAL OFFICE
}

\section{Wahyu Bawono' ${ }^{1)}$, Singmin Johannes Lo ${ }^{2)}$}

${ }^{1,2)}$ Master Of Management, Universitas Mercu Buana, Jakarta, Indonesia

ARTICLE INFORMATION

Received: $1^{\text {st }}$ March 2020

Revised: $15^{\text {th }}$ April 2020

Issued: $6^{\text {th }}$ May 2020

Corresponding author: Wahyu

\section{Bawono}

E-mail:

wahyubawono91@yahoo.com

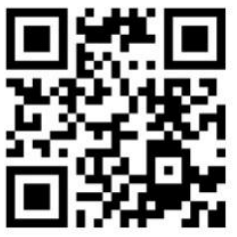

DOI:10.31933/DIJMS
Abstract: The objectives of this study are: (1) To analyze the Effect of Job Stress, Career Development and Job Satisfaction on Turnover Intention in PT PKSS and (2) To analyze the significant influence between Job Stress, Career Development and Employee Engagement simultaneously / Jointly towards Turnover Intention at PT PKSS. This research uses a quantitative method with a sample of all employees at PT PKSS, amounting to 98 people. The analysis technique used is Part Least Square Analysis (PLS). While the variables in this study are: (1) job stress, (2) career development, (3) employee engagement, and (4) turnover intention. The results of this study include: (1) Job stress has a significant effect on employee engagement with a T-Statistic value of 5,481 , (2) Career development has a significant effect on employee engagement with a TStatistic value of 4,909, (3) Work stress has a significant effect on turnover intention with a T-value Statistics of 3.071 , (4) Career development has a significant effect on turnover intention with a $\mathrm{T}$ Statistic value of 5.526, and (5) Employee employee variable can mediate jointly from the effect of work stress and career development on turnover intention. Can be proven by the analysis of VAF (Variance Accounted For) value calculation above, it can prove hypothesis 8 that employee engagement variable (Y1) can mediate the effect of work stress variables and career development together on turnover intention of $21.15 \%$.

Keywords: career development, work stress, employee engagement, turnover intention 


\section{INTRODUCTION}

Human resources are needed by a company as a system manager to achieve the objectives to be are several aspects that must be considered in managing human resources so that the company's system can run well achieved. There such as motivation, potential development, training, compensation, satisfaction, commitment and other aspects.

Human resources are the main assets of a company so that its role and function cannot be replaced by other resources. As the competition between companies, the human resources department has a role to help the company's line managers to encourage the company in achieving its goals. One effort to achieve the desired target or goal of the company is to prevent or minimize the level of employee turnover intention by taking into account all the factors that cause the employee's desire to move in response to a situation where employees begin to feel or find work conditions that are not in accordance with what is expected. Important spotlight for every company or office. This turnover phenomenon also occurs in one company, PT Prima Karya Sarana Sejahtera.

PT Prima Karya Sarana Sejahtera (PT. PKSS) is a company engaged in services. PT PKSS was established on July 15, 1999 and has a high commitment and dedication as a company engaged in HR solutions to support the operational activities of partner companies. The company PT PKSS has managed around 43,000 people and more than 200 companies have collaborated with PT PKSS both BUMN and multinational. PT PKSS already has a network of 34 branch offices spread throughout Indonesia. The types of service products include Assessment, Recruitment, Job Analysis, Employment Providers / Employment Services, Education and Training. PT PKSS is a partner and consultant for business both in terms of human capital, organization and management system.

Based on interviews with the Head of PT PKSS Business Division, information was obtained that there was a problem regarding the high level of turnover intention. This is very disturbing work system in PT PKSS. With the high turnover rate, an employee has to back up the work left by the employee who left so as to create an excessive workload. In addition, the Head of the PT PKSS Business Division stated that in 2018 there was an increase in the number of employees leaving with a range of up to 13 people, with a percentage of $16 \%$ so that it disrupted the existing system in the company because the tolerance level of turnover intention was $5 \%$ so that this phenomenon was categorized as a problem . The average reason for workers leaving is because they want a more promising place to work in terms of career path. High turnover rates make companies have to spend money to re-recruit employees. So this makes the company's cost burden increases.

Next the researchers conducted a survey about the phenomenon of turnover intention at PT PKSS to strengthen the results of the interview. The results of the survey are the turnover rate at PT. PKSS the last 3 years the highest is $16 \%$. It is very difficult to determine what a certain size the level of turnover of a company cannot be tolerated. However, there was an opinion from the Head of PT PKSS Business Division who said that the employee turnover ratio was outside the tolerance limit when it reached $5 \%$ or more in 1 year. This is as expressed by Edward Rosemand (2017) that if the company's turnover reaches 10\%, then the company turnover category is said to be high. So it can be concluded that the turnover that 
occurred at PT. PKSS is included in the high category, this is evidenced by the level of outgoing employees has exceeded $10 \%$, which is $16 \%$.

The author conducted a pre-survey at PT PKSS head office which was followed by respondents as many as 15 employees randomly. This pre-survey was conducted so that the writer know how employees perceptions about the tendency to leave the company and also to find out problems related to turnover intention. There are indications of turnover intention problems which are indicated among other things there is a desire / plan to quit the job and often try to find another job. Furthermore, indications of problems regarding work stress are shown, among others, often feeling there is psychological pressure in doing work and having excessive workload. In addition, an indication of career development problems can also be seen in the results of the pre-survey, which is satisfied with the existing promotion system in the company and the training obtained enables to do work at a higher career level. While the indication of the last problem seen in the pre-survey results is about employee engagement feel less empowered according to my abilities and the company does not give the trust to work on projects / important task.

Researchers also conducted interviews with several employees who had signs of turnover intention behavior. In line with the results of the pre-survey questionnaire, the interviewed employees stated that there was an excessive workload obtained by each employee, and the promotion system was also not very clear. This resulted in loyalty to the company continues to decline and they began to think about finding a new job that they think is better than the current job.

Job stress has a positive influence on the desire to leave the organization (turnover intention). These influences indicate that excessive workload, lack of clarity of authority given is not in accordance with responsibilities, conflicts in the organization, differences in perceptions at work and the small amount of income received which creates a separate workload for employees and causes high stress and impacts on the desire to leave the organization. Relatively high pressure will cause physical health problems, mental health and lack of well-being can lead to work stress, and can reduce employee productivity.

Based on the phenomena mentioned above, the researcher is interested in taking this theme into an empirical study entitled "Employee Engagement As A Mediator Influences Of Work Stress And Career Development To Turnover Intention In Employee Office Of PT Pkss Central Office".

\section{LITERATURE REVIEW}

Job Stress

Stress is a feeling of pressure or feeling depressed experienced by an employee in dealing with work (Mangkunegara, 2011). According to Sopiah (2008), factors causing work stress among physical environments, stress due to roles or tasks, interpersonal stress, and organization. According Istijanto (2010) several dimensions that can be used as a reference to determine stress caused by work, namely: (1) Conflict and Role Conflict \& Ambiguity, (2) Career Development, and Responsibility (Responsibility). 


\section{Career Development}

According to Dessler (2016) career development is a series of lifelong activities that contribute to the exploration, formation, success, and fulfillment of one's career. Forms of career development within a company are usually different from one another in terms of education, transfer between departments, and promotion (Kasmir, 2016). In line with Dessler (2013), Mathis and Jackson (2010) states that the measuring tools used to measure career development are (1) Career Management, (2) Career Planing, and (3) Succession Planning.

\section{Employee Engagement}

Gallup Consulting (2017) states that "Employee engagement as those who are involved in, enthusiastic about and committed to their work and workplace". According to Scheimann (2011: 224), there are several goals of employee engagement, namely (1) Growth and development, (2) Recognition, (3) Engagement, (4) Supervisor, (5) Successful experience, The employee dimension engagement that is vigor, dedication and absoption (Schaufeli \& Bakker, 2010).

\section{Turnover Intention}

Staffelbach (2008) describes turnover intention is a subjective possibility where an individual will change his work within a certain period of time and is a basic pioneer to the actual turnover. According to Andini (2016), a high level of turnover intention can cause an organizational ineffectiveness due to the loss of experienced individuals and positions left behind. According to Armstrong (2009) several reasons for leaving work because (1) Higher pay, (2) Better career paths, (3) Better opportunities to develop skills, (4) Better security, (5) Conditions better work, (6) Unable to cope with work, (7) Poor relations with superiors, (8) Poor relations with colleagues, (9) Harassment, (10) Personal reasons.

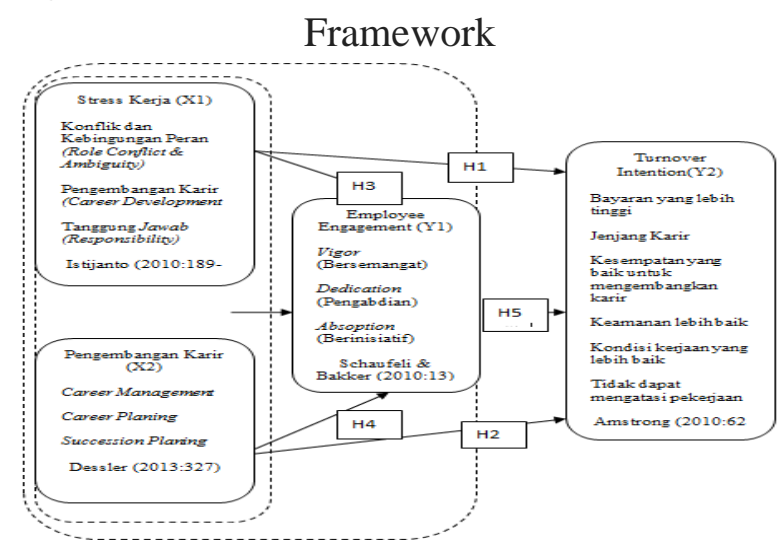

Picture 1. Thinking Framework Hypothesis

H1: Job Stress has a significant effect on PT PKSS Employee Turn Over Intention.

H2: Career Development has a significant effect on PT PKSS Employee Turn Over Intention.

H3: Job Stress has a significant effect on PT PKSS Employee Engagement.

H4: Career Development has a significant effect on PT PKSS Employee Engagement.

H5: Employee Management significantly mediates Job Stress and Career Development towards PT PKSS Employee Turn Over Intention. 


\section{RESEARCH METHODS}

This research uses quantitative research methods. The research method chosen for this study uses survey research or non-experimental research, namely survey information from a portion of the population (respondent samples) collected directly at the scene empirically, by knowing the opinions of some populations on the object being studied (Arikunto, 2012).

The population in this study were all employees at PT PKSS, amounting to 98 people. The author uses a saturated sampling technique that is the technique of determining the sample if all members of the population are used as samples, namely 98 samples. Data collection techniques in this research include (1) Field Research, and (2) Library Research. While the data analysis technique uses Smart PLS version 3 software which is run on computer media.

\section{FINDINGS AND DISCUSSION}

\section{Converging Validity Test}

Test of convergent validity is done by examining, among others, individual item reliability, internal consistency, or construct reliability, and average variance extracted. Based on the results of data processing with SmartPLS version 3.0, it can be seen that indicators of work stress variables, career development, employe engagement and turnover intention have a loading factor $>0.50$. This shows that all indicators of the work stress variable is valid and is still used in the model or not excluded from the model.

\section{Discriminant Validity}

The discriminat validity test is based on the value of cross loading measurements with constructs and the value of Average Variance Extracted (AVE). Cross Loading factor to determine whether latent variables have adequate discriminant by comparing the correlation between indicators with other latent variables (Yamin, 2009). Based on the results of the discriminant validity test, it can be seen that the value of construct correlation with the indicator is greater than the value of correlation with other constructs. Thus it can be concluded that all latent constructs show good discriminant validity because they can predict indicators in their block better than indicators in other blocks. All latent constructs show good discriminant validity because they can predict indicators in their block better than indicators in other blocks. Next to discriminant validity testing is done by looking at the value of AVE (Average Variance Extracted). AVE value is good if it has a value greater than 0.50 . The test results show the AVE value of the research model for all research variables has a value above 0.5 so that the value of AVE for discriminant validity testing has met for further testing. Thus, the Discriminant Validity test has been fulfilled as well as the Convergent Validity test so that it can be concluded that the research model has been Valid.

\section{Reliability Test Results}

Reliability test is a reliability test that aims to find out how far the measuring instrument can be relied on or trusted. Another test to evaluate the outer model is to look at the construct reliability of latent variables measured by two different sizes, namely the composite reliability of the indicator block that measures the construct. The first stage, the construct is declared reliable if has a composite reliability value above 0.70 (Ghozali \& Latan, 2012). The composite reliability value of the research model shows that each variable has a composite reliability value above 0.7 with the lowest value of 0.947 from the Work 
Stress variable (X1) and the highest value of 0.986 from the Employee Engagement variable (Z). From these results it can be concluded that the research model has met the value of composite reliability.

\section{Multicollinearity Test}

Multicollinearity test aims to test whether there is a high relationship between variable items. There is no multicollinearity if the VIF value is below 5. The multicollinearity test results above obtained each item has a VIF below 5 . Therefore it can be concluded that there is no multicollinearity in the SEM model in this study.

\section{Descriptive Research Statistics}

Descriptive statistical analysis of the research variables is used to determine the tendency of the answers to the questionnaire or the extent to which respondents responded according to the choice of answers category using a Likert scale from scale 1 (strongly disagree) to 5 (strongly agree) to the statements of each variable. The data collected is then tabulated to find out the distribution of respondents' answers from each indicator on each research variable as shown in the appendix. The results of the frequency distribution of variable turnover intentions indicate that the majority of the answers to the question items are evenly distributed on the answer choices disagree, agree, and strongly agree. Each item has an average of above 2.00 so that it can be interpreted in general respondents rated turnover intention is quite high. Items that have a low average peling is the 12th item with an average of 2.94 and the highest third item is 3.70 .

\section{Structural Testing of the Model (Inner Model)}

1. Determination / R Square Coefficient Test $\left(\mathrm{R}^{2}\right)$

Evaluation of the inner model is done by looking at the coefficient of determination. The coefficient of determination aims to measure how far the model's ability to explain the variance of the dependent variable. The R-square value of the Employee Engangement $(\mathrm{Z})$ variable is 0.814 , this shows that $81.4 \%$ of the Employee Engangement $(\mathrm{Z})$ variable can be influenced by the variable Job Stress (X1) and Career Development (X2) while the remaining $18.6 \%$ is influenced by other variables beyond those studied. The R-square value of the Turnover Intention (Y) variable is 0.833 , this shows that $83.3 \%$ of the Turnover Intention (Y) variable can be influenced by the variable Job Stress (X1), Career Development (X2), and the Employee Engangement variable ( Z), while the remaining $16.7 \%$ is influenced by other variables outside the study.

\section{Hypothesis Test Results}

Hypothesis testing between constructs is done by bootstrapping resampling method. Calculation of Hypothesis Testing using SmartPls 3.2.7 can be seen from the Path Coefficient value, which is the t-statistic value of the relationship between variables in the study. The analysis technique used in this study is a structural equation model (Structural Equation Modeling-SEM) based on variance or Component based SEM, which is famously called Partial Least Square (PLS). In this section consists of direct influence and indirect influence. The analysis technique used in this study is a structural equation model (Structural Equation Modeling-SEM) based on variance or Component based SEM, which is famously called Partial Least Square (PLS). The following are the results of the structural equation obtained: 


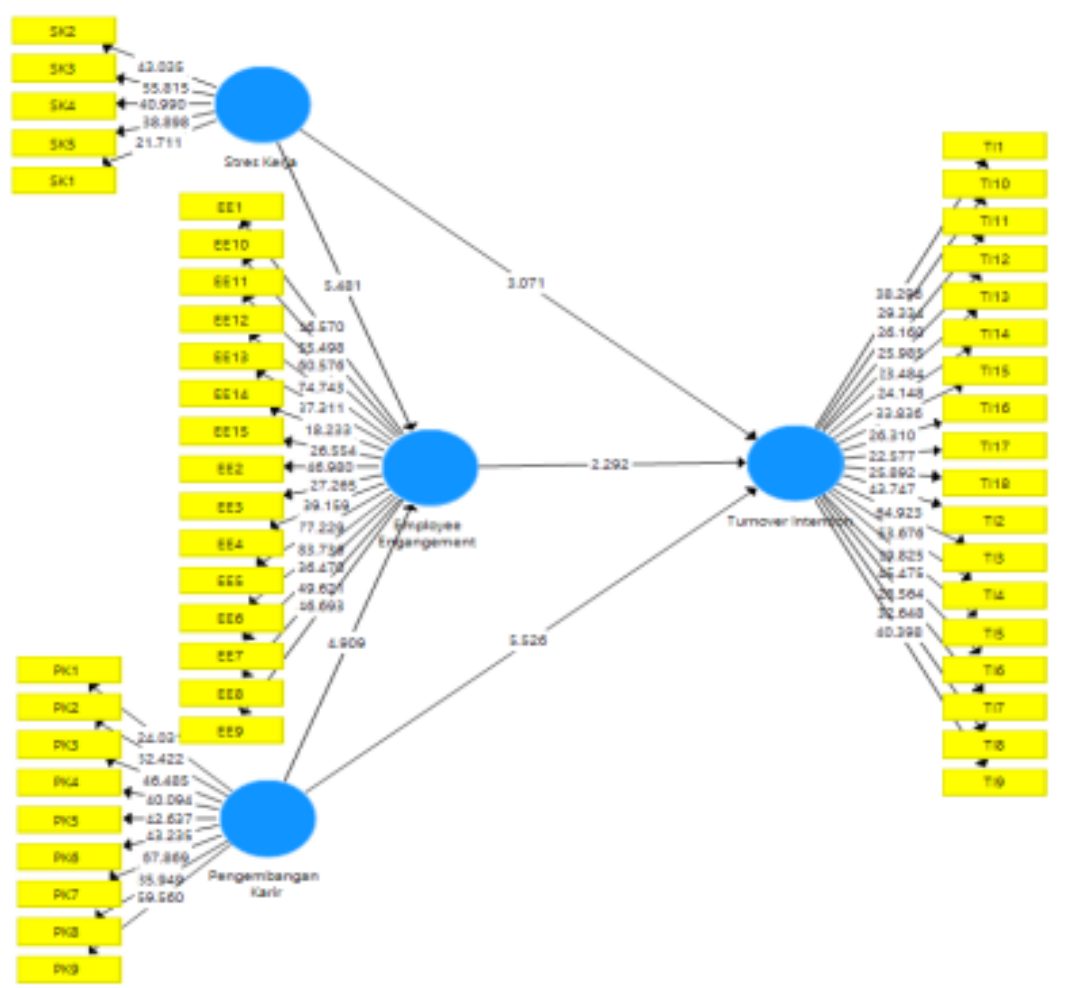

\section{Picture 4.2 Results of Path Analysis Using Smart PLS}

Work stress has a significant effect on turnover intention with a T-Statistic value of 3.071 and P-Values of 0.001 so that the significance value is less than 0.05 . The coefficient of the influence of work stress on turnover intention is 0.283 which means a positive influence. Career development has a significant effect on turnover intention with a T-Statistic value of 5.526 and P-Values of 0.000 so that the significance value is less than 0.05 . The coefficient of the influence of career development on turnover intention is -0.464 which means a negative influence. Work stress has a significant effect on employee engagement with a T-Statistic value of 5.481 and P-Values of 0,000 so that the significance value is less than 0.05 . The coefficient of the influence of work stress on employee engagement is -0.504 which means there is a negative influence. Career development has a significant effect on employee engagement with a T-Statistic value of 4.909 and P-Values of 0,000 so that the significance value is less than 0.05 . The coefficient of the influence of career development on employee engagement is 0.427 , which means there is a positive influence. Evaluation of mediating variables in this study uses the construct of employee engagement (Y1) which aims to scientifically prove the indirect effect of work stress variables and career development on turnover intention. This test is based on tests of direct effects, indirect effects and total effects presented in the following for structural models.

The relationship between latent variables is tested through the Variance Accounted approach. For (VAF) is used to determine the magnitude of the mediation effect of the relationship. According to Cohen (1988) grades. VAF can be calculated using the formulation as follows. $\mathrm{VAF}=($ Indirect Effect $/$ Total Effect $) \times 100 \%$.

The results of the VAF calculation above, can prove hypothesis 5 that the employee engangement variable (Y1) can mediate the effect of work stress variables and career development together on turnover intention of $21.15 \%$. 


\section{Evaluate the value of $\mathbf{R} 2$}

Evaluating the value of $\mathrm{R} 2$ based on the results of calculations using calculate SmartPLS version 3.0 obtained the value of R2 on the effect of work stress variables and career development on employee engangement of 0.814 or $81.4 \%$. Variable work stress, career development, and employee engagement towards turnover intention are 0.833 or $83.3 \%$. The value of $\mathrm{R} 2$ indicates that the level of determination of exogenous variables (compensation and work climate) towards the endogenous is quite high.

Simultaneous test or F test in this study aims to determine the joint effect of the variable 1 work stress and career development on employee engangement. Second, to find out the joint effect of work stress variables, career development, and employee engangement on turnover intention.

1. Variable work stress and career development can affect employee engangement by 0.814 or $81.4 \%$. The simultaneous influence of work stress variables and career development on employee engangement can be done by calculating $\mathrm{f}$ arithmetic / $\mathrm{f}$ statistics using the formula as below.

$$
\begin{aligned}
& \mathrm{R}^{2}=0,814(\mathrm{Y} 1) \\
& \mathrm{F} \text { arithmetic }=\frac{\frac{R^{2}}{(k-1)}}{1-R^{2} /(n-k)} \\
& \mathrm{F} \text { arithmetic }=\frac{\frac{0.814}{(3-1)}}{1-0,814 /(98-3)} \\
& \mathrm{F} \text { arithmetic }=0,407 / 0,002 \\
& \mathrm{~F} \text { arithmetic }=207,876
\end{aligned}
$$

The $\mathrm{F}$ value of the table at $(\mathrm{df} 1=3-1$; $\mathrm{df} 2=98-3)$ alpha 0.05 is 3.092 . This means that $\mathrm{f}>\mathrm{f}$ table then there is a simultaneous effect of stress work and career development towards employee engagement.

2. vVariable work stress, career development, and employee engangement are able to influence turnover intention by 0.833 or $83.3 \%$. The simultaneous influence of work stress variables, career development, and employee engangement on turnover intention can be done by calculating $\mathrm{f}$ arithmetic / f statistics using the formula as below.

$$
\begin{aligned}
& \mathrm{R}^{2}=0,833(\mathrm{Y} 2) \\
& \mathrm{F} \text { arithmetic }=\frac{\frac{R^{2}}{(k-1)}}{1-R^{2} /(n-k)} \\
& \text { Farithmetic }=\frac{\frac{0.833}{(4-1)}}{1-0,833 /(98-4)} \\
& \mathrm{F} \text { arithmetic }=0,278 / 0,002 \\
& \mathrm{~F} \text { arithmetic }=156,291
\end{aligned}
$$

The F value of the table at ( $\mathrm{df} 1=4-1$; $\mathrm{df} 2=98-4)$ alpha 0.05 is 2.701 . This means that $\mathrm{f}>\mathrm{f}$ table then there is a simultaneous influence of work stress, career development, and employee engangement on turnover intention. 


\section{Validate the Overall Structural Model with the Goodness of Fit Index}

The purpose of testing the Goodness of Fit Index $(\mathrm{GoF})$ is to validate the combine performance of the measurement model (outer model) and the structural model (inner model) obtained through calculations as follows:

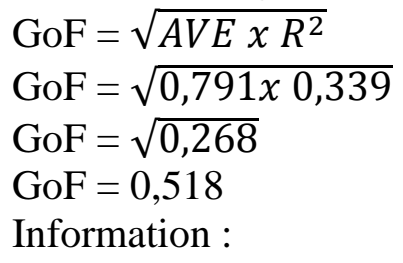

$\mathrm{AVE}=(0,783+0,808+0,824+0,748) / 4=3,163 / 4=0,791$

$\mathrm{R}$ square $=(0,814 \mathrm{x} 0,833) / 2=0,339$

The calculation result of the Goodness of Fit Index (GoF) shows the value of 0.518 . Based on these results it can be concluded that the combined performance of the measurement model (outer model) and the structural model (inner model) as a whole is good because the Goodness of Fit Index $(\mathrm{GoF})$ value is more than 0.23 (moderate scale).

\section{Predictive Relevance (Q2) Testing}

The purpose of testing predictive relevance $(\mathrm{Q} 2)$ is to validate the model. The results of the Q2 calculation are as follows:

$$
\begin{aligned}
& \mathrm{Q} 2=1-\left(1-\mathrm{R} 1^{2}\right)\left(1-\mathrm{R} 2^{2}\right) \\
& \mathrm{Q} 2=1-(1-0,814)(1-0,833) \\
& \mathrm{Q} 2=1-(0,186)(0,167) \\
& \mathrm{Q} 2=1-0,031 \\
& \mathrm{Q} 2=0,969
\end{aligned}
$$

Based on the predictive relevance (Q2) calculation above, it shows a value of 0.969 . In this research model, endogenous latent variables have predictive relevance (Q2) values greater than 0 (zero) so that exogenous latent variables are suitable as explanatory variables that are able to predict their endogenous variables in other words prove that this model is considered to have good predictive relevance.

\section{Analysis of Correlation Between Dimensions}

Correlation analysis is a statistical analysis that measures the degree of relationship involving more than one independent variable (X1, X2, Y1) and one dependent variable (Y2).

\begin{tabular}{|c|c|c|c|c|}
\hline \multirow[t]{2}{*}{ Variabel } & \multirow[b]{2}{*}{ Dimensi } & \multicolumn{3}{|c|}{ Employe Engagement (Y1) } \\
\hline & & $\begin{array}{c}\text { Vigor } \\
\text { (Bersemangat) } \\
\text { (Y1.1) }\end{array}$ & $\begin{array}{c}\text { Dedication } \\
\text { (Pengambidian) } \\
\text { (Y1.2) }\end{array}$ & $\begin{array}{l}\text { Absoption } \\
\text { (Y1.3) }\end{array}$ \\
\hline \multirow[t]{3}{*}{ Stress Kerja (X1) } & $\begin{array}{l}\text { Role Overload } \\
\text { Quantitative \& } \\
\text { Time Availability }\end{array}$ & $-0,716$ & $-0,714$ & $-0,685$ \\
\hline & $\begin{array}{l}\text { Career } \\
\text { Development }\end{array}$ & $-0,779$ & $-0,816$ & $-0,831$ \\
\hline & Responsibility & $-0,833$ & $-0,838$ & $-0,840$ \\
\hline \multirow[t]{3}{*}{$\begin{array}{l}\text { Pengembangan } \\
\text { Karir (X2) }\end{array}$} & $\begin{array}{l}\text { Career } \\
\text { Management }\end{array}$ & 0,697 & 0,725 & 0,749 \\
\hline & Career Planing & 0,747 & 0,799 & 0,813 \\
\hline & $\begin{array}{l}\text { Succession } \\
\text { Planning }\end{array}$ & 0,814 & 0,854 & 0,867 \\
\hline
\end{tabular}
Dimension correlation analysis is used to determine the relationship between the dimensions of the variable Job Stress (X1) and Career Development (X2) to the Employee Engangement (Y1) and Turnover Intention (Y2) variables.

Table 4.19 Dimension Correlation Results for Employee Engangement

Source: Primary data processed 
In the correlation variable dimensions of work stress and career development of employee engangement obtained all dimensions have a significant relationship to employee engangement. The highest vigor dimension has a correlation with the responsibility dimension which is -0.833 . The highest dimension of dedication has a correlation with succession planning that is 0.854 . The highest absorption dimension has a correlation with succession planning that is 0.867 .

Table 4.20

Dimension Correlation Results for Employee Engangement and Turnover Intention

\begin{tabular}{|c|c|c|c|c|c|c|c|c|c|c|}
\hline \multirow[b]{2}{*}{ Variabel } & \multirow[b]{2}{*}{ Dimensi } & \multicolumn{9}{|c|}{ Turnover Intention (Y2) } \\
\hline & & Bayaran & $\begin{array}{l}\text { Jenjang } \\
\text { Karir }\end{array}$ & $\begin{array}{l}\text { Kesempatan } \\
\text { Lebih Baik }\end{array}$ & $\begin{array}{c}\text { Keamanan } \\
\text { Lebih } \\
\text { Baik }\end{array}$ & $\begin{array}{c}\text { Kondisi } \\
\text { Kerja }\end{array}$ & $\begin{array}{l}\text { Mengatasi } \\
\text { Pekerjaan }\end{array}$ & $\begin{array}{l}\text { Hubungan } \\
\text { Dengan } \\
\text { Atasan }\end{array}$ & $\begin{array}{l}\text { Hubungan } \\
\text { Dengan } \\
\text { Rekian }\end{array}$ & Pelecehan \\
\hline \multirow{3}{*}{ Stress Kerja (XI) } & $\begin{array}{c}\text { Role Overload Quantitative } \\
\text { \& Time Availability }\end{array}$ & 0,540 & 0,571 & 0,634 & 0,615 & 0,002 & 0,718 & 0,680 & 0,690 & 0,649 \\
\hline & Career Development & 0,757 & 0,770 & 0,789 & 0,765 & 0,778 & 0,812 & 0,810 & 0,805 & 0,765 \\
\hline & Responsibility & 0,694 & 0,693 & 0,687 & 0,707 & 0,734 & 0,801 & 0,767 & 0,765 & 0,753 \\
\hline \multirow{3}{*}{$\begin{array}{c}\text { Pengembangan } \\
\text { Karit }(X 2)\end{array}$} & Career Mamagement & 0.048 & $-0,654$ & $-0,697$ & $.0,673$ & $.0,686$ & $.0,682$ & $.0,684$ & $.0,657$ & $-0,690$ \\
\hline & Career Planing & $-0,757$ & $-0,764$ & $.0,755$ & $-0,771$ & $.0,742$ & $-0,779$ & $.0,765$ & $.0,728$ & 0,732 \\
\hline & Succession Planning & $.0,799$ & 0,799 & $-0,820$ & $-0,761$ & $0,0,09$ & $-0,841$ & $-0,788$ & $.0,806$ & 0,008 \\
\hline \multirow{3}{*}{$\begin{array}{c}\text { Employee } \\
\text { Engongement } \\
\text { (Y1) }\end{array}$} & Vigor (Bersemangat) & $-0,660$ & $-0,656$ & $-0,730$ & 0,067 & $\cdot 0,690$ & $.0,005$ & $.0,804$ & $.0,816$ & $-0,761$ \\
\hline & Dedication (Pengambidian) & $.0,719$ & $-0,718$ & $-0,758$ & $.0,743$ & $.0,740$ & $-0,813$ & $-0,818$ & $.0,829$ & $.0,782$ \\
\hline & Absoption & $.0,730$ & $.0,726$ & $.0,802$ & $.0,756$ & $.0,749$ & $.0,19$ & $.0,807$ & $.0,794$ & $.0,763$ \\
\hline
\end{tabular}

Source: Primary data processed

In the correlation of dimensions of work stress, career development, and employee engangement, all dimensions have a significant relationship to turnover intention. The highest paid dimension has the highest correlation with the succession planning dimension that is 0.799 . The highest career dimension has a correlation with succession planning that is 0.854 . The dimension of a better chance of the highest has a correlation with absoption that is 0.802 . The higher security dimension has the highest correlation with career planing which is $-0,771$. The highest dimension of working conditions has a correlation with succession planning that is $-0,809$. The highest dimension of overcoming work has a correlation with succession planning that is $-0,809$. The highest relationship dimension with superiors has a correlation with dedication that is $-0,818$. The highest dimension of relations with colleagues has a correlation with dedication that is $-0,829$. The highest dimension of harassment has a correlation with succession planning that is $-0,808$.

\section{CONCLUSION AND SUGGESTION}

The conclusions of the results of research on the effect of turnover intention on employees at PT PKSS Headquarters are as follows:

1. There is a significant influence of work stress with turnover intention. The coefficient of the influence of work stress on turnover intention means a positive effect. This means that the higher the work stress, the higher the turnover intention.

2. There is a significant influence of career development with turnover intention. The coefficient of the influence of career development on turnover intention means a negative influence. This means that the higher the career development, the lower the turnover intention.

3. There is a significant influence of work stress with employee engagement. The coefficient of the influence of work stress on employee engangement means that there is a negative 
influence. This means that the higher the work stress, the lower employee engagement will be.

4. There is a significant influence of career development with employee engagement. The coefficient of the influence of career development on employee engangement means that there is a positive influence. This means that the higher the career development, the higher employee engagement will be.

5. Employee engangement variables can mediate together from the influence of work stress and career development on turnover intention

\section{REFERENCE}

Arikunto, Suharsimi. (2012). Prosedur Penelitian. Rineka Cipta. Jakarta.

Armstrong (2009)

Dessler, Gary. (2016). Manajemen Sumber Daya Manusia, Jilid 1 Edisi 10. Indeks . Jakarta.

Dessler. (2013). Manajemen Sumber Daya Manusia Human Reources, Jilid 2, Prenhalindo, Jakarta.

Edward Rosemand (2017)

Gallup Consulting. (2017). U.S. Employee Engagement. Washington D.C.

Istijanto, Oei. (2010). Riset Sumber Daya Manusia. PT. Gramedia Pustaka Utama, Jakarta.

Kasmir. (2016). Analisis Laporan Keuangan. Raja Grafindo Persada. Jakarta.

Mangkunegara, A. Prabu. (2011). Manajemen Sumber Daya Manusia Perusahaan. Rosdakarya. Bandung.

Schaufeli \& Bakker, 2010).

Schiemann, W. A. (2011). Aligment Capability Engagement. PPM Manajemen. Jakarta.

Sopiah (2008),

Staffelbach , B. (2008). Turnover intent. Diploma Thesis. Strategie-und. Unversity of Zurich. Unter, 